\title{
Release and dispersion of vegetation and peat fire emissions in the atmosphere over Indonesia 1997/1998
}

\author{
B. Langmann and A. Heil \\ Max-Planck-Institut für Meteorologie, Hamburg, Germany \\ Received: 6 February 2004 - Published in Atmos. Chem. Phys. Discuss.: 20 April 2004 \\ Revised: 5 September 2004 - Accepted: 9 October 2004 - Published: 3 November 2004
}

\begin{abstract}
Smoke-haze episodes caused by vegetation and peat fires affect parts of Indonesia every year with significant impacts on human health and climate. Particularly fires in degenerated peat areas release huge amounts of trace gases, e.g. $\mathrm{CO}_{2}, \mathrm{CO}$ and $\mathrm{CH}_{4}$, and particles into the atmosphere, exceeding by far the emissions per unit area from fires in surface vegetation. However, only limited information is available about the current distribution of pristine and degenerated peat areas in Indonesia, their depth, drainage condition and modification by fire. Particularly during the strong El Niño event in 1997/1998 a huge uncertainty exists about the contribution of Indonesian peat fire emissions to the measured increase of atmospheric $\mathrm{CO}_{2}$, as the published estimates of the peat area burned differ considerably. In this paper we study the contribution of peat fire emissions in Indonesia during the El Niño event 1997/1998. A regional three-dimensional atmosphere-chemistry model is applied over Indonesia using two emission estimates. These vegetation and peat fire emission inventories for Indonesia are set up in $0.5^{\circ}$ resolution in weekly intervals and differ only in the size of the fire affected peat areas. We evaluate simulated rainfall and particle concentrations by comparison with observations to draw conclusions on the total carbon emissions released from the vegetation and peat fires in Indonesia in 1997/1998.
\end{abstract}

\section{Introduction}

Every year during the dry season, land clearing fires are set in Indonesia. Usually the burning activities cease in October/November with the beginning of the northern monsoon rains. The strong El Niño of 1997/1998, however, lead to severe drought conditions. Land-clearing fires became uncontrolled particularly on Kalimantan (Borneo) and Suma-

Correspondence to: B. Langmann

(langmann@dkrz.de) tra. Reduced convective activity during August until October 1997 favoured wide-spread dispersion of the vegetation fire emissions causing several episodes of intense smoke-haze that affected also Malaysia and Singapore. Close to the vegetation fires at Palangkaraya on Kalimantan and Jambi on Sumatra up to $4000 \mu \mathrm{g} / \mathrm{m}^{3}$ total particulate matter was measured, exceeding the Indonesian national ambient air quality standard by a factor of 15 (Heil and Goldammer, 2001).

Levine (1999) estimated the emissions released from the fires on Kalimantan and Sumatra islands between August and December 1997. Although this study assumed only $20 \%$ of the area burned to consist of peat areas, these regions contributed about $90 \%$ of the gaseous and particulate fire emissions. The reason is the huge storage of organic matter in the peat deposits that has accumulated over the last 5000 to 10000 years (Rieley et al., 1995). The majority of the estimated 170000 to $270000 \mathrm{~km}^{2}$ of peat swamps in Indonesia is deeper than $1 \mathrm{~m}$, frequently more than $15 \mathrm{~m}$ in depth (Rieley et al., 1997). Peat areas have become increasingly susceptible to fire in the past decades due to an intensification of their drainage for land conversion purposes.

The amounts of gaseous, particularly $\mathrm{CO}_{2}, \mathrm{CO}$ and $\mathrm{CH}_{4}$ and particulate matter emissions released from peat fires in Indonesia are still rather uncertain, as well as the particle chemical composition (Langmann and Graf, 2003). Fires in peat areas may affect both the above-ground vegetation as well as the below-ground organic soil which can burn repeatedly at different depths. Peat fires are typically lowtemperature, smouldering fires which are difficult to detect from space. The determination of emissions released from peat fires is further complicated by the necessity to characterise additionally the soil and the depth of the soil burned. Generally, large uncertainties exist in the determination of the area burned during fire episodes. The uncertainties are reflected in the estimated areas of fire damaged peat lands during the strong El Niño event in 1997 in Indonesia which range from 14500 to $68047 \mathrm{~km}^{2}$ (Page et al., 2002) resulting 
in a calculated range of 480 to $2570 \mathrm{Mt}$ of carbon released into the atmosphere. These emissions are equivalent to 13 $40 \%$ of the mean annual global carbon emission from fossil fuels and represent a significant contribution and uncertainty to the largest annual increase of atmospheric $\mathrm{CO}_{2}$ detected since record began in 1957 (IPCC, 2001).

Recently, global climatological biomass burning emission inventories have been improved by means of satellite data to include an interannual variability (e.g. Duncan et al., 2003). However, peat fires as a major source for gases and particles are not included in these inventories explicitly. In this paper we present a spatial-temporal resolved vegetation and peat fire emission estimate for Indonesia during 1997/1998. We applied the three-dimensional regional atmospheric-chemistry model REMO (REgional MOdel) introduced in Sect. 2 over the region of Indonesia with two different peat fire emissions estimates described in Sect. 3 . The emission estimates and model results are evaluated by comparing the modelled atmospheric aerosol load with measurements (Sect. 4). Section 5 draws conclusions on the total carbon emissions from the Indonesian fires in 1997/1998 and gives an outlook.

\section{Model description}

The regional three-dimensional on-line atmospherechemistry model REMO (Langmann, 2000) determines at every model time step the physical and chemical state of the model atmosphere. The dynamical part of the model is based on the regional weather forecast model system EM/DM of the German Weather Service (Majewski, 1991). Beside the German Weather Service physical parameterisations, those of the global ECHAM-4 model (Roeckner et al., 1996) have been implemented in REMO (Jacob, 2001) and are used for the current study. The prognostic equations for surface pressure, temperature, specific humidity, cloud water, horizontal wind components and aerosol mass mixing ratios are written on an Arakawa-C-grid (Mesinger and Arakawa, 1976).

In the current model set-up, one prognostic species is included, representing the atmospheric aerosol without further differentiation according to the chemical composition and size distribution. Particle emissions are assumed to be released into the first model layer, because smouldering fires which are typical for fires in peat areas generally do not cause strong convective lifting. Although secondary aerosol formation may play an important role, it is not included in the present study. The particle transport is determined by horizontal and vertical advection according to the algorithm of Smolarkiewitz (1983), convective up- and downdraft by a modified scheme of Tiedtke (1989) and vertical diffusion after Mellor and Yamada (1974). Due to the elevated sulfur content of Indonesian vegetation and peat fire aerosols (Langmann and Graf, 2003) particle deposition is calculated as for sulfate. Dry deposition velocities are determined as described by Walcek et al. (1986) dependent on the friction velocities and stability of the lowest model layer. Wet deposition is computed according to Walcek and Taylor (1986) by integrating the product of the grid-averaged precipitation rate and the mean cloud water concentration, assuming $100 \%$ solubility of the particles as not only sulfate but also water soluble organic compounds contribute to the hygroscopicity of the particles (Balasubramania et al., 2003; Narukawa et al., 1999; Okada et al., 2001).

For this study the REMO model was applied with 20 vertical layers of increasing thickness between the Earth's surface and the $10 \mathrm{hPa}$ pressure level using terrain following hybrid pressure-sigma coordinates. The model domain covers Indonesia and Northern Australia (Fig. 1) with a horizontal resolution of $0.5^{\circ}$ and 101 grid points in longitude and 55 grid points in latitude with the lower left corner at $91^{\circ} \mathrm{E}$ and $19^{\circ} \mathrm{S}$. A basic model time step of 5 min was chosen. REMO can be applied principally in two modes, the so-called "climate mode" or the "forecast mode". In the climate mode the model is initialised once and then run continuously until the end of the simulation period with an update of the meteorological analysis data every $6 \mathrm{~h}$ at the lateral model boundaries. Between these six hour intervals the analyses are interpolated linearly in time. Meteorological analysis data are taken from European Center for Medium Range Weather Forecast with time varying fields of surface pressure, temperature, horizontal wind velocities and moisture. In the forecast mode the model is started at 0 UTC every day to compute a $30 \mathrm{~h}$ forecast and the analysis data are also updated every $6 \mathrm{~h}$. The first six hours of the consecutive meteorological forecasts are neglected to account for a spin-up time. The total simulation period is composed of $24 \mathrm{~h}$ simulation segments with a discontinuity in the physical state of the atmosphere at 6 UTC. But, by starting the model again every day the internal model variability is suppressed and the model is forced to stay close to the observed weather situation. Particulate matter processes, however, are calculated continuously like in the climate mode. This is done by simulating meteorology only in the first six hours of each $30 \mathrm{~h}$ forecast. Then, combined particle matter and meteorology calculations continue for $24 \mathrm{~h}$ starting with the particulate matter information from the last time step of the previous forecast.

Previous studies and evaluation with the REMO atmosphere-chemistry model give confidence in the ability of the model to reproduce the physico-chemical state of the atmosphere. The model has been applied with various trace species modules to study for example summer smog episodes over Europe (e.g. Langmann et al., 2003), to determine the distribution and radiative forcing of sulfate aerosols over Europe (Langmann et al., 1998) and the Arctic region and to investigate $\mathrm{CO}_{2}$ and ${ }^{222} \mathrm{Rn}$ fluxes and distributions over Euro-Siberia (Chevillard et al., 2002a, b). Recently, stable water isotope physics has been implemented in REMO. 
a)

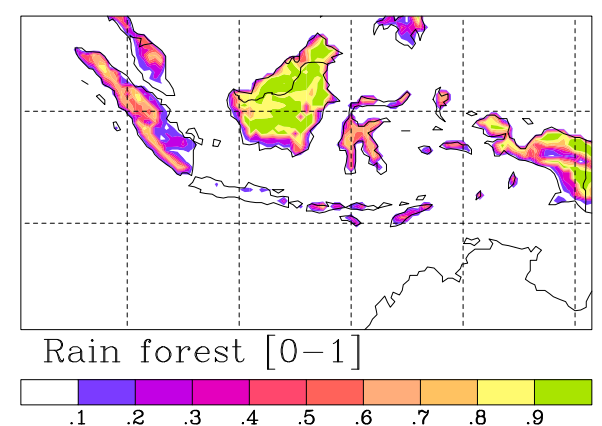

c)

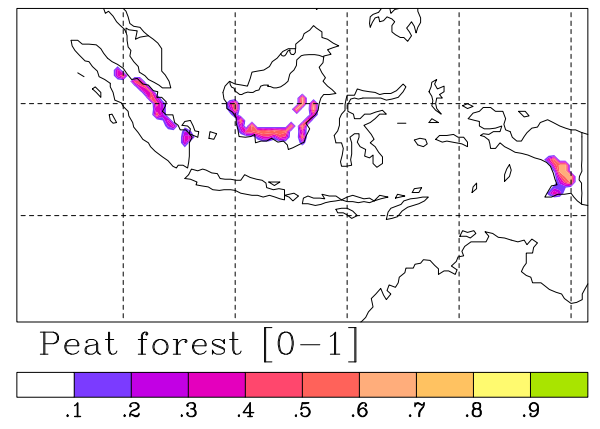

b)

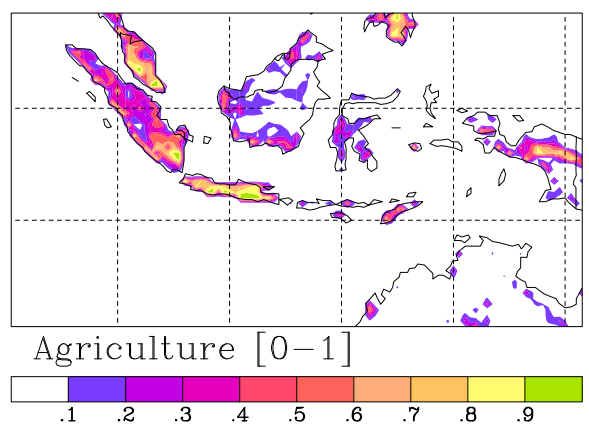

d)

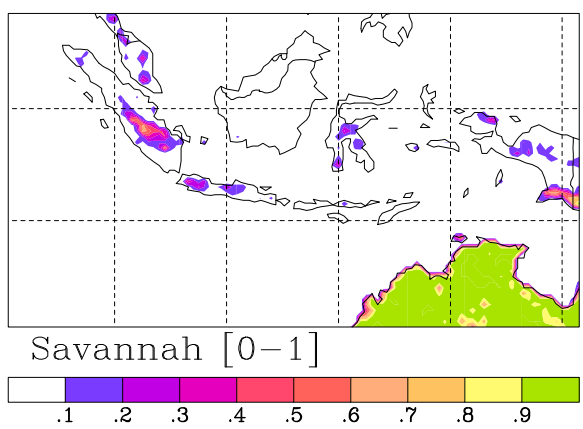

Fig. 1. Distribution of the major vegetation classes as used in the REMO model domain in fraction $(0-1)$ per model grid cell $\left(0.5^{\circ} \times 0.5^{\circ}\right)$ for (a) rain forest, (b) agriculture, (c) peat forest and (d) savannah.

\section{Emission estimate}

In this section we introduce our approach to derive the emissions of aerosols and trace gases from vegetation and peat fires in Indonesia during the period July 1997 to June 1998. We proceed in four steps: 1. set-up of vegetation maps, 2. collection of remotely sensed fire count data, 3 . determination of area burned with spatial and temporal variability and 4. estimate of fire emissions.

\subsection{Vegetation cover}

In the first step we prescribed the distribution of four major vegetation classes: rain forest, agriculture, peat forest and savannah as fraction per model grid cell (Fig. 1). This is based on a vegetation data set of Loveland et al. (2000) in $1 \times 1 \mathrm{~km}^{2}$ resolution derived with the AVHRR sensor during April 1992 and March 1993. We did not consider modifications of the vegetation cover between 1993 and 1997 due to the lack of data. Rain forests are found mainly on Borneo and Irian Jaya. Southern Sumatra, Java and the Peninsula of Malaysia represent the highest agricultural use while savannah is the main vegetation type only in Northern Australia. Peat forests are not defined in Loveland et al. (2000) and we supplemented this vegetation class using information from maps published by Nichol (1997) and Dierke Weltatlas (1980). Figure 1c shows peat forests mainly located near the coast of east Sumatra, Kalimantan and south-eastern Irian Jaya. The fraction of peat forest per grid cell in these areas was calculated assuming that it makes up $2 / 3$ of the total forest cover.

\subsection{Fire counts from remotely sensed data}

We determined the temporal and spatial distribution of vegetation and peat fires in Indonesia by using fire counts from the ATSR sensor (Arino and Rosaz, 1999) on board the ESR-2 satellite in $1 \times 1 \mathrm{~km}^{2}$ resolution. A threshold of $312 \mathrm{~K}$ (algorithm 1) or $308 \mathrm{~K}$ (algorithm 2) is applied to the radiance of the $3.7 \mu \mathrm{m}$ channel in order to detect fires. We used the ATSR pixels above the $312 \mathrm{~K}$ threshold and incorporated them in weekly intervals into the REMO model grid. Figure 2 shows the number of ATSR fire counts per model grid cell from 1 July to 31 December 1997 and from January 1 to 30 June 1998, respectively. The areas with the highest fire count density were located in southern Kalimantan and south-eastern Sumatra in 1997 with more than 1000 fire counts per grid cell and in 1998 in East-Kalimantan with more than 500 fire counts per grid cell. According to our estimates, peat forests make up 20 to $60 \%$ of the total vegetation cover in these regions (Fig. 1c). 
(a)

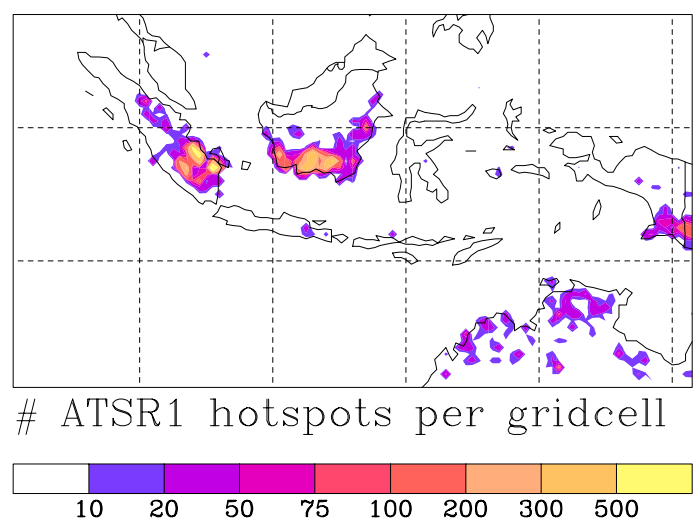

(b)

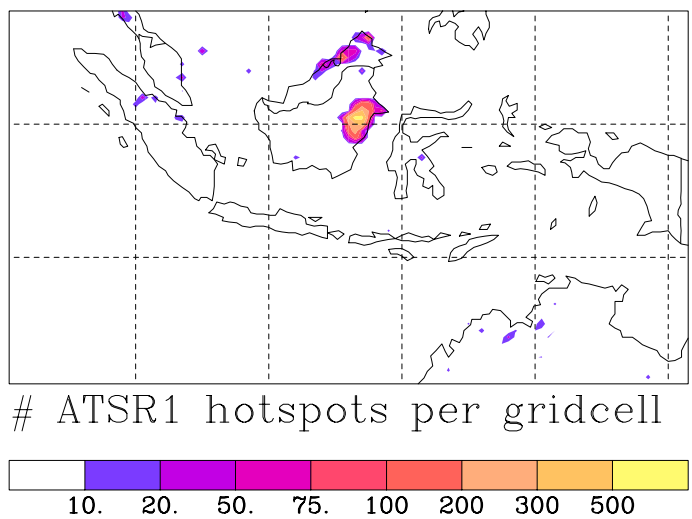

Fig. 2. Number of ATSR fire counts per model grid cell over Indonesia (a) during the period from 1 July to 31 December 1997 and (b) from 1 January to 30 June 1998.

\subsection{Area burned}

The ATSR fire count data over Indonesia were converted into area burned information, subdivided into the four vegetation classes utilised in this study, using the following empirical relationship:

$$
A B_{i}=\operatorname{MIN}(F C / \alpha, 1 / \beta) * A * V_{i}
$$

with

$A B_{i}$ : area burned of vegetation class $i$ per model grid cell and week $\left(\mathrm{km}^{2}\right)$,

$F C$ : fire counts per model grid cell and week,

$A$ : area per model grid cell $\left(\mathrm{km}^{2}\right)$,

$V_{i}$ : fraction of vegetation class $i$ per model grid cell,

$\alpha, \beta$ : empirical parameters.

The empirical parameter $\alpha=554$ scales the area burned per week to less than the total area per grid cell. It is further assumed that not more than $1 / \beta$ with $\beta=14$ of a grid cell may burn during one week. A weekly interval is chosen to assure at least two overpasses of the ESR-2 satellite thereby smoothing the ATSR data. Both empirical parameters represent fit-
Table 1. Area burned estimates $\left(\mathrm{km}^{2}\right)$ for the Indonesian fire period 1997/1998. Left column: ADB/Bappenas (1999), middle column: standard estimate of this study, right column: high emission estimate of this study.

\begin{tabular}{lrrr}
\hline Area burned $\left(\mathrm{km}^{2}\right)$ & ADB (1999) & Standard case & High emission case \\
\hline Total Indonesia & 96550 & 97340 & 151290 \\
\hline Kalimantan & 65000 & 56940 & 96060 \\
Sumatra & 17550 & 29080 & 40300 \\
Irian Jaya & 9000 & 8260 & 11870 \\
Sulawesi + Java & 5000 & 3060 & 3060 \\
& & & \\
Rain forest & $34710^{1}$ & 39640 & 39640 \\
Agriculture & $39630^{2}$ & 35930 & 35930 \\
Peat forest & 14580 & 14190 & 68140 \\
Savannah & $7630^{3}$ & 7590 & 7590 \\
\hline
\end{tabular}

${ }^{1}$ sum of lowland forest and timber plantation

2 sum of agriculture and estate crops

${ }^{3}$ dry scrub and grass

ting constants that approximately adjust the ATSR fire counts for the model area north of $10^{\circ} \mathrm{S}$ (excluding Northern Australia) to the total area burned of $96550 \mathrm{~km}^{2}$ in Indonesia during 1997/1998 given by ADB/Bappenas (1999). This study compiles various assessments by Indonesian agencies and international organisations based either on satellite data, aerial surveillance or ground assessments for different regions and vegetation classes (Table 1, left column).

A comparison of the area burned estimate given by ADB/Bappenas (1999) and our "standard" estimate (Table 1, middle column) shows very similar values for the area burned per vegetation class but major differences for Kalimantan and Sumatra. With our approach we obtain a smaller area burned on Kalimantan and a greater one on Sumatra, revealing limitations to accurately estimate the area burned from satellite derived fire counts. First, the presence of clouds and haze (Siegert and Hoffmann, 2000) prevents a continuous and consistent detection of hot spots. Second, for the ATSR fire count product only night time observations are used which leads to an underestimation since fire activity generally peaks in the afternoon. Third, a fire pixel represents a defined area of $1 \mathrm{~km}^{2}$. It indicates that a heat event is detected within this area, however, it tells nothing about the number, the size and the intensity of the fires and thus the area burned within this pixel (Malingreau, 1990). Fourth, the relatively low temperature and partly subsurface peat fires might be difficult to detect from space by commonly used temperature thresholds (Anderson, 2001).

In addition to our standard estimate, a "high emission" estimate has been established where solely the area of the fire damaged peat forest during 1997/1998 has been increased by a factor of 4.8 compared to the standard estimate resulting in 
Table 2. Biomass load (B) in $\mathrm{t} / \mathrm{km}^{2}$ and dimensionless burning efficiency (E), carbon content (C), combustion efficiency (CE), emission factor (EF) and $\mathrm{CO}_{2}$-normalised species emission ratios (ER) for rain forests, agricultural and peat areas in Indonesia based on Levine (1999). For savannah we use the same parameters as for agriculture.

\begin{tabular}{lrcccccc}
\hline & $\mathrm{B}\left[\mathrm{t} / \mathrm{km}^{2}\right]$ & $\mathrm{E}$ & $\mathrm{C}$ & $\mathrm{CE}$ & $\mathrm{EF}(\mathrm{TPM})$ & $\mathrm{ER}(\mathrm{CO})$ & $\mathrm{ER}\left(\mathrm{CH}_{4}\right)$ \\
\hline Rain forest & 10000 & 0.2 & 0.45 & 0.90 & 0.020 & 0.0850 & 0.0032 \\
Agriculture $^{1)}$ & 5000 & 0.2 & 0.45 & 0.90 & 0.020 & 0.0850 & 0.0032 \\
Peat areas & $97500^{2)}$ & 0.5 & 0.5 & 0.77 & 0.035 & 0.1815 & 0.0104 \\
\hline
\end{tabular}

1) agriculture and plantation areas

2) $1.5 \mathrm{~m}$ deep peat deposits

$68140 \mathrm{~km}^{2}$ (Table 1, right column). This number represents the upper estimate of fire damaged peat lands in Indonesia during 1997 given by Page et al. (2002). As a result the total area burned in Indonesia during 1997/1998 in the high emission case is $151290 \mathrm{~km}^{2}$. The area burned by sub-regions increases considerably on Kalimantan and Sumatra in the high emission case while it remains unchanged on Sulawesi and Java where peat forest is assumed to be negligible in our estimate (Fig. 1c). The peat area burned per grid cell and week does not exceed $25 \%\left(\sim 750 \mathrm{~km}^{2}\right)$ for the high emission estimate and $5 \%\left(\sim 150 \mathrm{~km}^{2}\right)$ for the standard estimate during the whole simulation period from July 1997 to June 1998.

\subsection{Fire emissions}

Particulate and gaseous emissions of the fires are determined based on the approach described by Levine (1999). Generally, the total mass of vegetation or peat consumed by burning ( $M$ in tons) is

$M=A B * B * E$

where $B$ is the biomass load in tons $/ \mathrm{km}^{2}$ and $E$ the burning efficiency. The total particulate matter emissions (TPM_E in tons) can then be determined by

$T P M_{-} E=M * E F(T P M)$

with $E F(T P M)$ as emission factor for total particulate matter (TPM). Gaseous emissions of $\mathrm{CO}_{2}\left(\mathrm{CO}_{2} E\right.$ in tons of carbon) are calculated by considering the carbon content of the fuel ( $C$ as mass percentage of carbon) and the combustion efficiency $C E$ :

$\mathrm{CO}_{2-} E=M * C * C E$

Emissions of other trace gases, notably $\mathrm{CO}$ or $\mathrm{CH}_{4}$ are calculated by multiplying $\mathrm{CO}_{2} E$ with a $\mathrm{CO}_{2}$-normalised species emission ratio (ER). Table 2 summarises the respective values of biomass load, burning efficiency, carbon content, combustion efficiency, emission factors and emission ratios for the different vegetation types used for our calculation. These values are fully taken from Levine (1999) and therefore we refer to that paper for more detailed information. At this
Table 3. Area burned $\left(\mathrm{km}^{2}\right)$ and TPM emissions (Mt) from $\mathrm{Au}-$ gust to December 1997 in Sumatra and Kalimantan according to Levine (1999) and the standard and high emissions estimate of this study.

\begin{tabular}{lcccc}
\hline Area burned $\left(\mathrm{km}^{2}\right)$ & Total & Peat forest & Rain forest & Agriculture \\
\hline Levine (1999) & 45600 & 9120 & 13680 & 22800 \\
Standard case & 58677 & 10650 & 18658 & 29369 \\
High emission case & 99147 & 51120 & 18658 & 29369 \\
\hline TPM (Mt) & Total & Peat forest & Rain forest & Agriculture \\
\hline Levine (1999) & 16.568 & 15.561 & 0.547 & 0.460 \\
Standard case & 19.506 & 18.172 & 0.746 & 0.588 \\
High emission case & 88.559 & 87.225 & 0.746 & 0.588 \\
\hline
\end{tabular}

point it has to be mentioned that we corrected for the further discussion in Eq. (5) and Table 2 of the publication of Levine (1999) the unit for particulate matter emissions from "tons of carbon" to "tons". The biomass load for peat deposits (Table 2) given by Levine (1999) is based on Supardi et al. (1993). It exceeds the one of rain forests by a factor of 10 because the sub-ground organic body (peat) is the major burning material and not the overlying vegetation. Together with the other factors used to calculate the emissions, the higher biomass load of peat deposits results in 43 and 85 times higher TPM emissions per unit area burned than rain forests and agriculture, respectively. This highlights the particular importance of peat fires as emission source.

Table 3 compares the estimate of Levine (1999) of the area burned on Sumatra and Kalimantan during August to December 1997 and the resulting particulate emissions with the results of our standard and high emission case for the same area and period. Compared to Levine (1999) we overestimate the area burned by $29 \%$ and the TPM emissions by $18 \%$ in the standard case. However, the relative contributions of the different vegetation classes is reproduced within $5 \%$ with our standard approach. In the high emission case, the area burned 


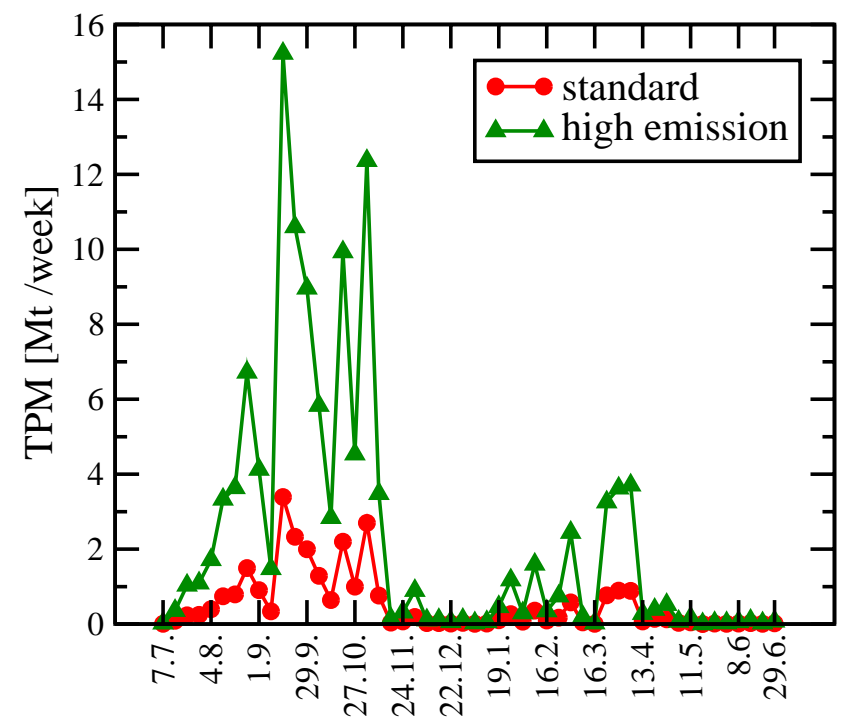

July 1997 - June 1998

Fig. 3. Temporal variability of total particulate matter (TPM) emissions from vegetation and peat fires in Indonesia and Northern Australia as determined for the standard and high emission case. The sum is $26.7 \mathrm{Mt} /$ year for the standard estimate and $118.7 \mathrm{Mt} /$ year for the high emission estimate, respectively.

exceeds the one given by Levine (1999) by a factor of 2.2 and TPM emissions are 5.3 times higher. Levine (1999) gives an overall uncertainty of $50 \%$ for his emission calculations. The results of the standard estimate are within these uncertainty limits while the TPM emissions of our high emission estimate exceed the uncertainty range by far. Although fires in peat areas contribute only $18 \%$ to the total area burned in our standard emission case, they produce more than $90 \%$ of the TPM emissions. This applies also to the emissions of trace gases such as $\mathrm{CO}_{2}, \mathrm{CO}$ and $\mathrm{CH}_{4}$. In the high emission case, fires in peat areas make up even $52 \%$ of the total area burned and $98 \%$ of the TPM emissions. These numbers illustrate again the enormous emissions released from peat fires.

Figure 3 displays the temporal variability of TPM emissions from vegetation and peat fires over Indonesia during the whole period from July 1997 to June 1998 as determined for the standard and high emission case. High amounts of TPM were released into the atmosphere during two fire periods. TPM emissions during the second fire period in 1998 were by a factor of 4.7 lower than in 1997 because a considerably smaller area was burned in 1998 (26\% of the total area burned in the standard case). Northern Australian emissions represent only $1.3 \%$ of the total emissions and were negligible compared to the Indonesian ones.

Page et al. (2002) emphasised the relevance of peat areas for climate change as they act as a source of $\mathrm{CO}_{2}$ when affected by fire. The authors estimated a release of 810 to $2570 \mathrm{Mt}$ of carbon to the atmosphere by burning forested peat areas in Indonesia in 1997. Page et al. (2002) classi- fied their lower estimate of $480 \mathrm{MtC}$ as an underestimate. Duncan et al. (2003) report emissions of about $700 \mathrm{MtC}$ for the 1997 Indonesian wildfires. In our standard estimate total carbon emitted from fires in Indonesia from July 1997 to June 1998 makes up 380 MtC (6\% of the mean annual global carbon emissions from fossil fuels), from which $\mathrm{CO}_{2}$ represents about $83 \%$, CO 14\%, TPM-carbon $2 \%$ and $\mathrm{CH}_{4} 1 \%$, respectively. In our high emission case $1600 \mathrm{MtC}$ are released to the atmosphere. However, this estimate is still significantly lower than the upper estimate of Page et al. (2002) of $2570 \mathrm{MtC}$, even though the same extent of fire-damaged peat areas is considered. The differences can be explained as follows: Page et al. (2002) assume a peat bulk density of $0.1 \mathrm{~g} / \mathrm{m}^{3}$, an averaged peat depths burned of $0.51 \mathrm{~m}$ and a peat carbon content of $57 \%$ resulting in $29070 \mathrm{t}(\mathrm{C}) / \mathrm{km}^{2}$ released by peat fires. Based on Levine (1999) only $24375 \mathrm{t}(\mathrm{C}) / \mathrm{km}^{2}$ are released by peat fires, resulting from a lower peat bulk density of $0.065 \mathrm{~g} / \mathrm{m}^{3}$, a lower carbon content of 50\%, but a higher effective peat depth burned of $0.75 \mathrm{~m}$. Furthermore, Page et al. (2002) assume the peat areas to be covered by pristine peat swamp forests with a biomass carbon content of $25000 \mathrm{t}(\mathrm{C}) / \mathrm{km}^{2}$ from which $50 \%$ is liberated by fire resulting in additional emissions of $400 \mathrm{MtC}$ in their upper estimate. However, mainly fragmented and logged over peat swamp forests are subject to fire. Therefore, we do not consider emissions from surface vegetation fires on peat areas in our emission estimates. In addition, it should be noted that the peat area burned estimate of Page et al. (2002) is based on a detailed investigation in a small, rather drained peat area in Central Kalimantan where 33\% were affected by fire in 1997 . This number was adopted to the peat areas all over Indonesia without any further modification, implying a general overestimation of the peat area burned.

\section{Model results and discussion}

The main goal of this study is to evaluate the two different emission estimates introduced in Sect. 3 by comparing the modelled spatial and temporal variability and intensity of smoke-haze from the 1997/1998 vegetation and peat fires in Indonesia with observations. The concentration and distribution of the particles depend on the emissions from the fires and also on meteorological factors including transport by advection, vertical redistribution by turbulent diffusion and convective clouds, chemical and microphysical modifications (not considered in the current study), and dry and wet deposition.

\subsection{General atmospheric conditions in Indonesia}

The tropical and wet conditions in Indonesia are characterised by uniformly high temperature, high humidity, relatively constant atmospheric pressure and weak wind 
(a) Area mean rainfall

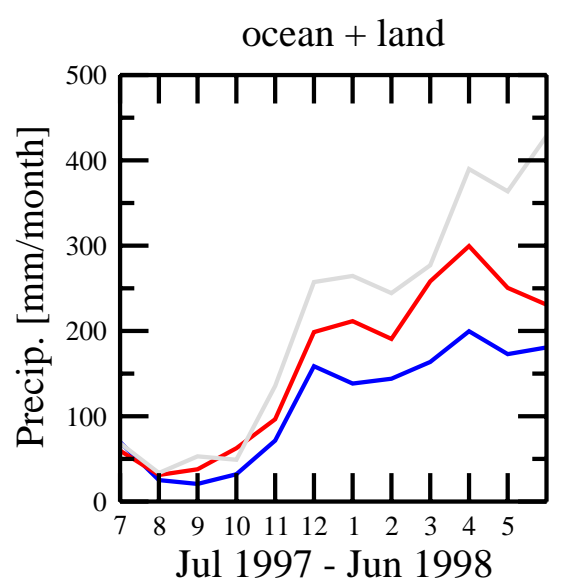

(b) Area mean rainfall land only

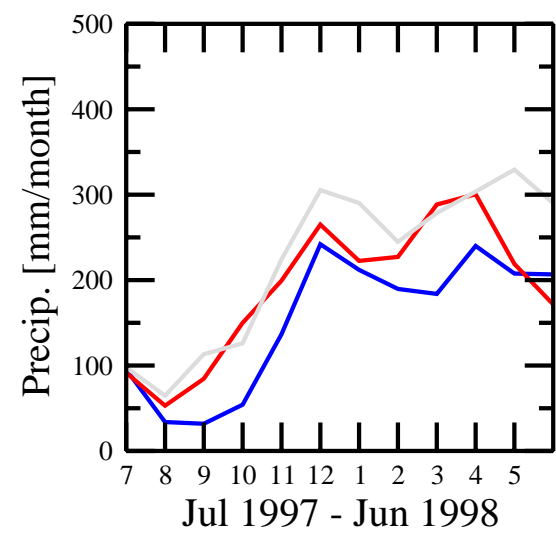

(c) Rainfall as mean

over 7 Malaysian stations

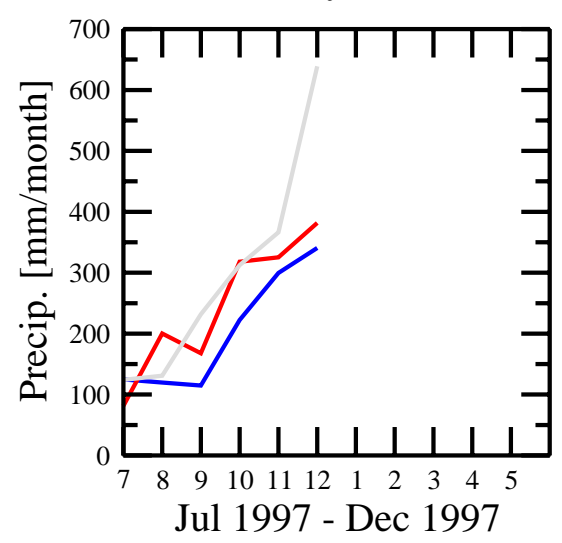

(d)
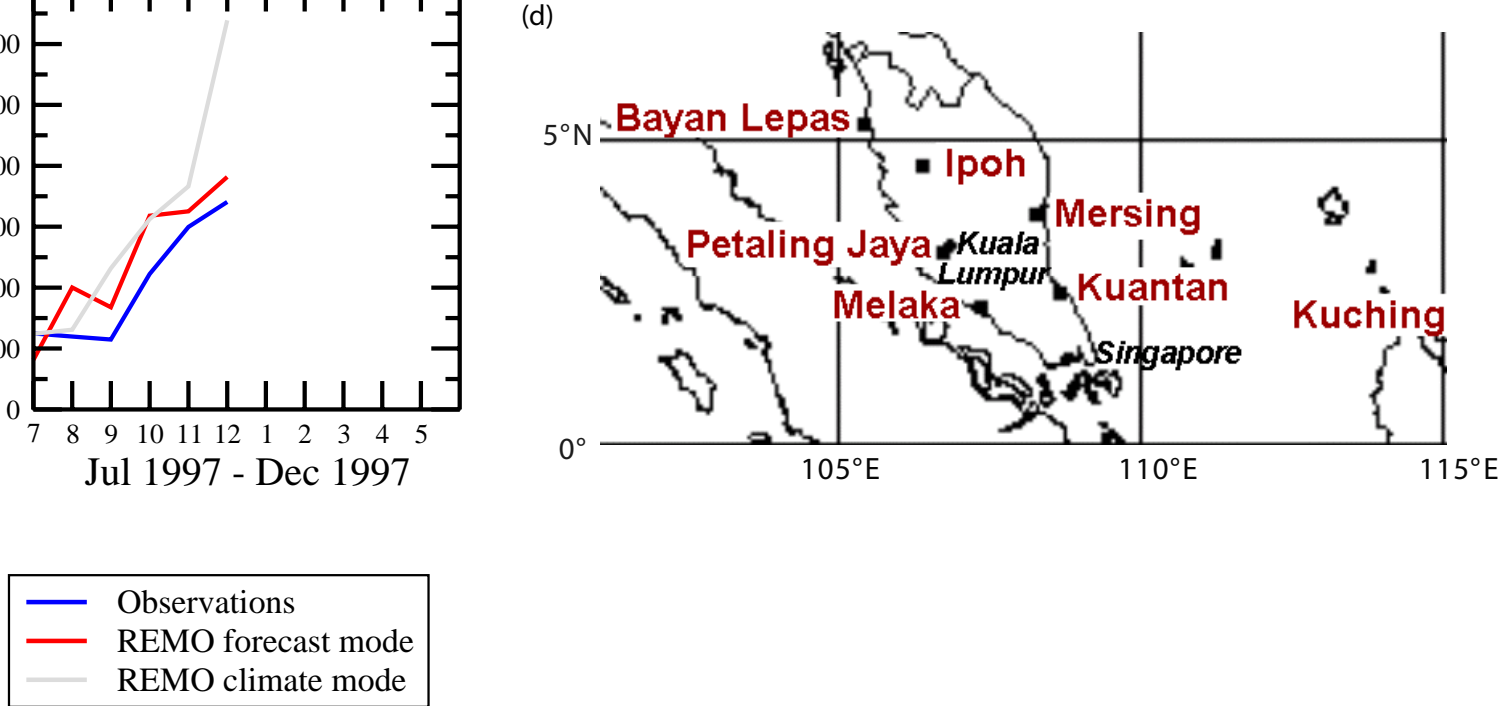

Fig. 4. (a) and (b) Area mean of monthly total precipitation over Indonesia $\left(96^{\circ}-136^{\circ} \mathrm{E}, 14^{\circ} \mathrm{S}-3^{\circ} \mathrm{N}\right)$ from July 1997 to June 1998 . Observations are taken from GPCC and GPCP. (c) Monthly total precipitation as mean over 7 Malaysian stations from July to December 1997. Observations are taken from the Malaysian Meteorological Service. REMO model results are shown for the climate and forecast mode simulation. (d) Location of the Malaysian stations.

velocities. The overall precipitation rate is highly variable in space and time in Indonesia (Aldrian, 2003) which represents the main centre of deep tropical convection on the Earth. Precipitation is therefore the quantity of greatest interest, particularly with respect to the removal of particles from the atmosphere by wet deposition, which is the dominant loss process.

Throughout the year Indonesia experiences a dry and a wet season induced by the two major flow patterns (Ramage, 1971). During the transitional months (September/October and April/May) the switching of the wind pattern results in relatively weak and variable winds. From about November to March low level trade winds blow in the northern hemisphere from the north-east towards the equator and continue into the southern hemisphere with a north-west component. This winter monsoon brings heavy rainfall to the Maritime Continent. The dry season from about June to September is characterised by the trade winds blowing from the south-east towards the equator in the southern hemisphere continuing in the northern hemisphere as south-west winds. During El Niño years, an additional suppression of precipitation occurs in Indonesia, which typically lasts for 13 months starting in March. 

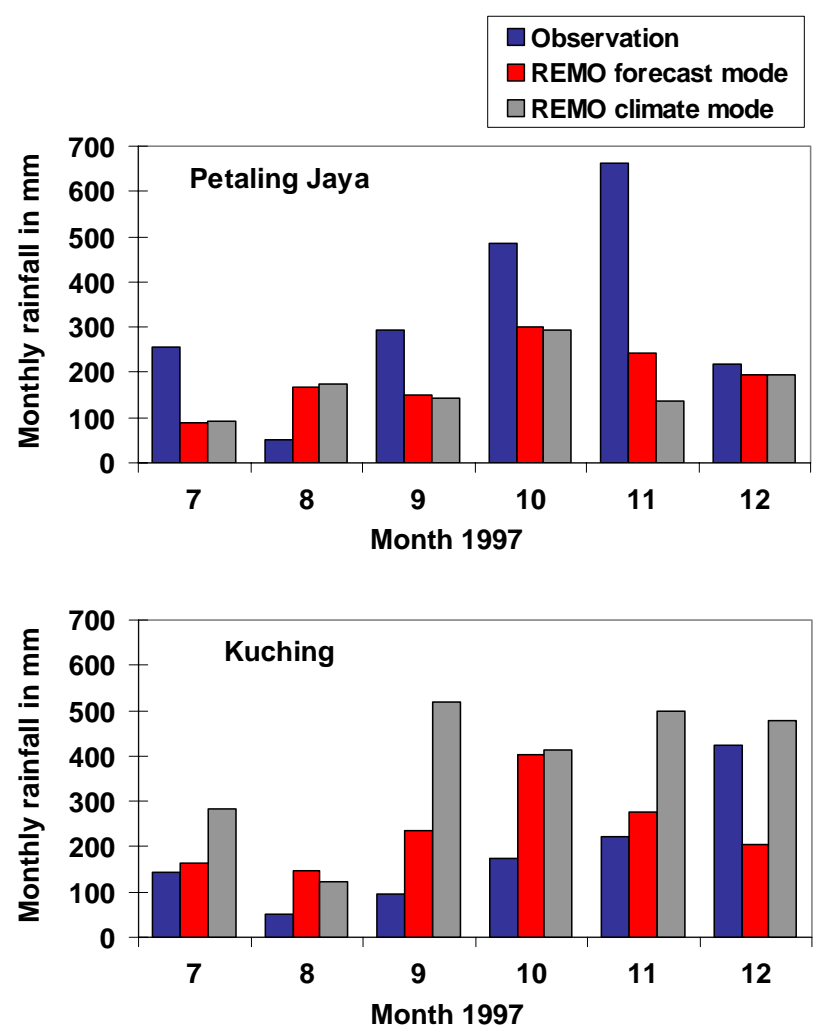

Fig. 5. REMO monthly rainfall from forecast and climate mode simulations versus measurements at (a) Petaling Jaya $\left(3.1^{\circ} \mathrm{N}\right.$, $\left.101.4^{\circ} \mathrm{E}\right)$ and (b) Kuching $\left(1.5^{\circ} \mathrm{N}, 110.3^{\circ} \mathrm{E}\right)$.

\subsection{The 1997/1998 El Niño period in Indonesia and} Malaysia

\subsubsection{Precipitation}

In 1997/1998, during one of the most severe El Niño events of the 20th century (McPhaden, 1999), precipitation in Indonesia was significantly reduced. An averaged monthly rainfall deficit of 120-150 mm below normal was recorded in Indonesia (WMO, 1998), the annual rainfall deficit ranged from 1000-1500 mm (FAO/GIEWS, 1998). Compared to a long-term rainfall record of 48 years, the rainfall from June to November 1997 was below the 10th percentile in large parts of Indonesia (Kirono et al., 1999).

A compilation of rainfall measurement data over land is available from the Global Precipitation Climatology Centre (GPCC, http://www.dwd.de/en/FundE/Klima/KLIS/int/ GPCC) as area-averaged monthly mean data. GPCC data are interpolated from rain gauge measurements to a $1^{\circ} \times 1^{\circ}$ geographical latitude-longitude grid over land. A combined dataset about rainfall over land and ocean is available from GPCP (Huffman et al., 1997). Over the ocean, GPCP data are based on infrared and microwave satellite observations, which are interpolated to a $2.5^{\circ}$ grid. Due to the scarcity of rain gauge measurements for the Indonesian region, an uncertainty of more than $10 \%$ over land and $40 \%$ over the ocean is attributed to this data (http://www.mpimet.mpg. de/en/extra/wg/wg5/wg_pr06.htm). Figure 4 illustrates the monthly total area averaged GPCC and GPCP rainfall and the corresponding REMO results for the climate and forecast mode from July 1997 to June 1998 for the whole area (ocean and land, Fig. 4a) and over land only (Fig. 4b). GPCC and GPCP data show dry conditions until November 1997 when the delayed northern monsoon rain started. The two maxima in rainfall during December 1997 and April 1998 are associated with the south- and northward movement of the Inter Tropical Convergence Zone. The REMO model reproduces the temporal development of measured rainfall data in detail, but yields principally higher precipitation rates. Overprediction by REMO is more pronounced in the climate mode than in the forecast mode as visible especially in Fig. 4a. We obtain similar results when comparing the average of monthly total precipitation measured at seven Malaysian stations (Fig. 4d) from July to December 1997 with the rainfall at the corresponding REMO grid points (Fig. 4c).

Strongly differing results are obtained when comparing rainfall records from single Malaysian stations with REMO results (Fig. 5). At Petaling Jaya/Kuala Lumpur (3.1 , $101.4^{\circ}, 46 \mathrm{~m}$ a.s.1.), observed monthly total precipitation exhibits a sharp increase from August reaching its maximum in November with $660 \mathrm{~mm}$ while rainfall modelled by REMO peaks in October with only around $300 \mathrm{~mm}$ (Fig. 5a). Over a 6-month total, REMO underpredicts observed precipitation (observed 6-month total of $1970 \mathrm{~mm}$ ) by $820 \mathrm{~mm}$ in the forecast mode and $1030 \mathrm{~mm}$ in the climate mode. At Kuching $\left(1.5^{\circ}, 110.3^{\circ}, 56 \mathrm{~m}\right.$ a.s.l. $)$ REMO generally overpredicts the observed rainfall, most pronounced in the climate mode (Fig. 5b). The 6-month total precipitation by REMO in the climate mode with $2320 \mathrm{~mm}$ is 2.1 times higher than the observation $(1010 \mathrm{~mm})$ while the REMO forecast mode is only $30 \%$ higher.

The observed and modelled rainfall in Indonesia and Malaysia (Figs. 4 and 5) exhibits strong variability in space and time. This highlights the difficulties of modelling convective clouds and precipitation with regional models such as REMO in this region of the world, where convective precipitation dominates over stratiform precipitation. It should be noted here, that model variables like wind speed and direction remain very similar in the forecast and climate mode simulations. As too much rainfall and associated wet deposition also influences the atmospheric particle burden, we focus in the following on the more realistic forecast mode simulation, unless noted otherwise. However, the spatial and temporal effectiveness of wet deposition might be affected by the physical discontinuity introduced once per day during the forecast mode simulation (Sect. 2). Additionally, the principal overprediction of precipitation in the whole area remains present in the forecast mode simulation, so that the modelled particle load of the atmosphere should be expected to present a lower boundary. 


\subsubsection{Wind speed and direction}

A comparison of observed and modelled monthly wind conditions at $925 \mathrm{hPa}$ at Petaling Jaya and Kuching is shown in Fig. 6 to illustrate the REMO model capabilities to determine particle transport by advection. The observations are based on 0 and 12 UTC sonde data obtained from the Malaysian Meteorological Services for the second half of 1997. Monthly wind speed is displayed as a box plot. The lower and upper edge of the box represents the 25th and 75th percentile value, respectively. The line across the box displays the median (50th percentile). Outliers are shown as squares, extreme values as stars. The wind roses in the upper band of Fig. 6 display the monthly number frequency of wind direction in $10^{\circ}$ sectors.

At Petaling Jaya, observed median wind speed exhibits a minimum in October and November 1997 as typical for the inter-monsoon period. REMO model results show similar features, but principally higher wind speeds, particularly in December. The interquartile range (length of the box) modelled by REMO indicating the variability of the values is in good agreement with the observations, except in December when the model produces a higher variability than observed. Measured wind direction at Petaling Jaya shows a switching from southerly to northerly monsoon winds in December. In between, there is a typical transitional phase with variable wind directions in October and November. REMO simulations reproduce the switching of the wind direction but, in contrast to the observations, do not show a period with changing wind directions. Higher modelled wind speeds may contribute to this bias since wind direction tends to become less variable with increasing wind speeds (Mestayer et al., 2003).

Observed monthly median wind speeds at Kuching (Fig. 6b) are nearly constant from July to December 1997. On a 6-month summary, the observed and the REMO model mean wind speed are almost equal. A comparison of the observed interquartile range of monthly wind speed with REMO results also shows good agreement. In both the observations and the REMO simulations, southerly winds predominate in July and August, followed by a period of highly variable wind directions turning into more frequent northerly winds by December. In summary, REMO fairly well reproduces observed changes of wind conditions with time giving confidence in modelled particle advection.

\subsubsection{Atmospheric smoke-haze distribution}

The spatial distribution of smoke-haze in Indonesia and Malaysia from July 1997 to June 1998 can be derived from the TOMS Aerosol Index (AI) data (Herman et al., 1997), shown in $1^{\circ}$ resolution as monthly means in the left column of Fig. 7. Positive TOMS AI values are derived from satellite measurements of UV absorbing aerosols in the entire vertical column of the atmosphere. Two periods of smoke-haze took
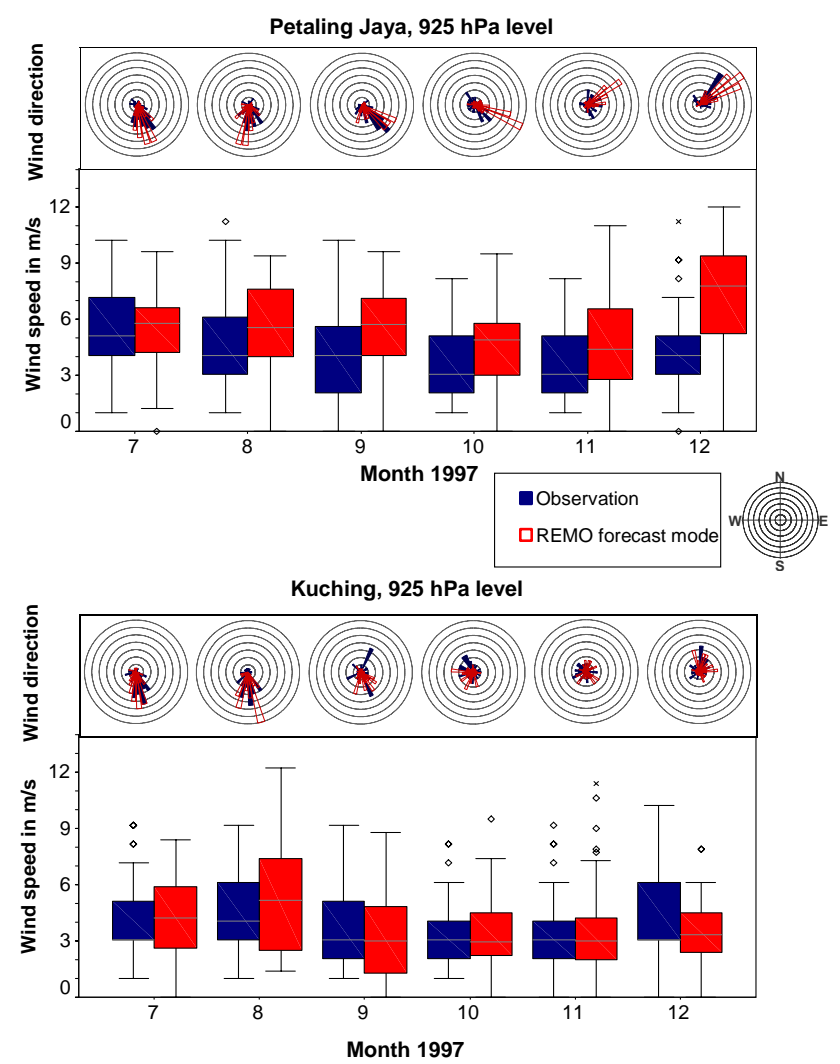

Fig. 6. REMO wind speed and direction in $925 \mathrm{hPa}$ versus measurements at (a) Petaling Jaya $\left(3.1^{\circ} \mathrm{N}, 101.4^{\circ} \mathrm{E}\right)$ and (b) Kuching $\left(1.5^{\circ} \mathrm{N}, 110.3^{\circ} \mathrm{E}\right)$.

place from August to November 1997 and from February to April 1998. During the first smoke-haze episode, TOMS AI exhibits maximum values over large parts of Sumatra and Kalimantan south of the equator, and southern Irian Jaya. The smoke-haze showed a strong west- and northward expansion from the main fire locations (Fig. 2). In September and October 1997, the smoke-haze reached far into the Indian Ocean and partially covered Peninsular Malaysia. In these months, fire emissions were highest (Fig. 3) while precipitation rates and associated wet deposition of smokehaze particles was low (Fig. 4). The second smoke-haze episode was restricted to Borneo only. TOMS AI maps in March and April 1998 show two separated smoke-haze plumes, one originating from fires in East Kalimantan and the other one mainly from fires in Borneo-Malaysia (eastern Sarawak and western Sabah) and Brunei. No substantial rainfall was recorded in East Kalimantan from January until April 1998, favouring the uncontrolled spread of fires in the region, whereas all the other provinces on Borneo had experienced normal to heavy rainfall (Siegert and Hoffmann, 2000).

The right column of Fig. 7 presents the monthly mean atmospheric column burden of total particulate matter as determined by the REMO model with the standard emission 


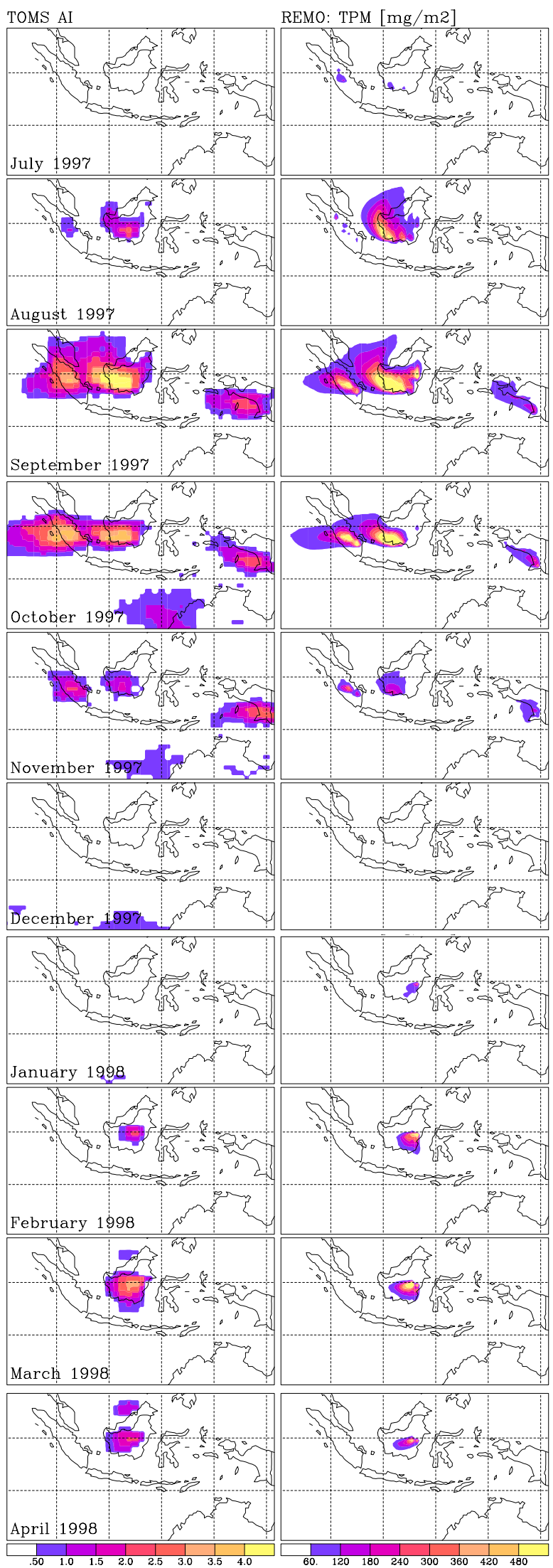

Fig. 7. Qualitative comparison of TOMS Aerosol Index in $1^{\circ}$ resolution (left column) with REMO calculated TPM column burden in $\mathrm{mg} / \mathrm{m}^{2}$ in $0.5^{\circ}$ resolution (right column) as monthly means from July 1997 to April 1998. During May and June 1998 TOMS AI and REMO calculated TPM column burden do not exceed the lowest colour interval of 0.5 and $60 \mathrm{mg} / \mathrm{m}^{2}$, respectively. Model results with the standard emission estimate are shown. 


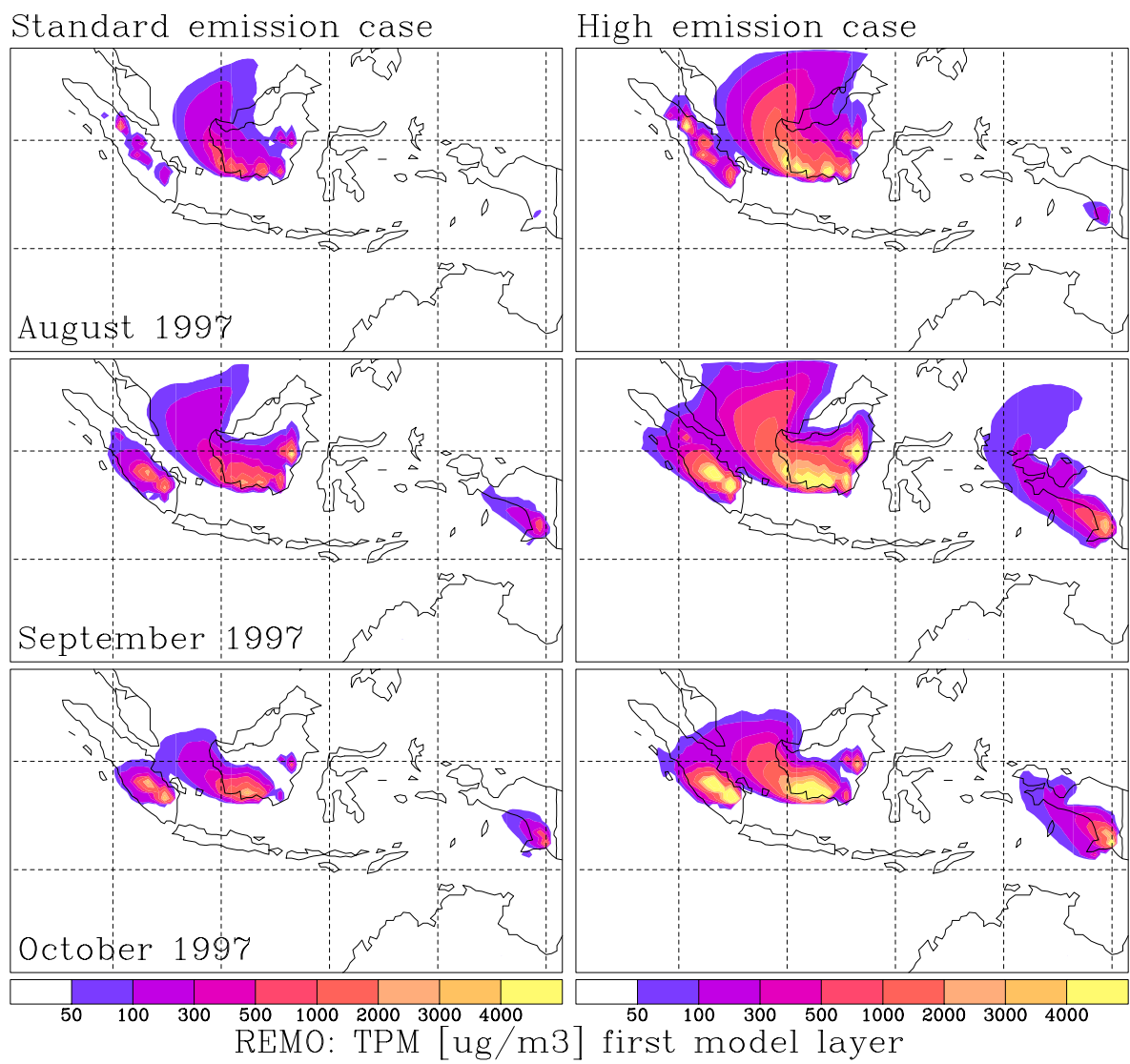

Fig. 8. Monthly mean TPM concentrations in $\mu \mathrm{g} / \mathrm{m}^{3}$ in surface air during the main haze period from August to October 1997 as determined by REMO for the standard emission case (left column) and the high emission case (right column).

estimate. It should be emphasised at this point that Fig. 7 displays only a qualitative comparison of the dimensionless TOMS AI with REMO calculated TPM column burden in $\mathrm{mg} / \mathrm{m}^{2}$ which however allows an evaluation of the simulated spatial and temporal variability of the smoke-haze distribution. The REMO model largely reproduces the spatial and temporal expansion and intensity of smoke-haze. A northward transport of smoke-haze dominates in the model results in August 1997, with an increasing westward motion until October 1997. Differences from TOMS AI occur in the modelled expansion and intensity of smoke-haze resulting from fires in Irian Jaya. A possible explanation for these disparities is that we may have underestimated the area of peat forests in south-eastern Irian Jaya. The REMO simulations also do not show a smoke-haze plume from fires in BorneoMalaysia and Brunei in 1998 as visible in TOMS AI data, because we did not estimate any peat fires there. AhmadZainal (2001), however, observed fires in Borneo-Malaysia in 1998 predominantly in peat forests.

\subsubsection{Smoke-haze distribution in surface air}

Monthly mean TPM concentration simulated for the first vertical model layer is shown in Fig. 8 for the standard and high emission estimate. The spatial expansion of the simulated smoke-haze for the two emission estimates exhibits similar dispersion patterns, but the smoke-haze in the high emission case is more extensive pointing to longer atmospheric residence times of TPM in this case. As expected, modelled TPM concentrations are distinctly higher in the high emission case. In September 1997 maximum monthly TPM concentrations of $5017 \mu \mathrm{g} / \mathrm{m}^{3}$ and $23814 \mu \mathrm{g} / \mathrm{m}^{3}$ are determined in the standard and the high emission cases, respectively, for the first model layer. In our standard estimate we determine monthly mean TPM concentrations above $2000 \mu \mathrm{g} / \mathrm{m}^{3}$ from August until October only for 15 model grid cells in areas with high fire activity, while in the high emission case they are determined over roughly the entire region with recorded fire activity (159 model grid cells). In the high emission case, TPM concentrations downwind from the fires remain at high levels over long distances. In September 1997, monthly mean TPM concentrations between 1000 and $2000 \mu \mathrm{g} / \mathrm{m}^{3}$ expand from the fire regions in southern Kalimantan into the 
(a)

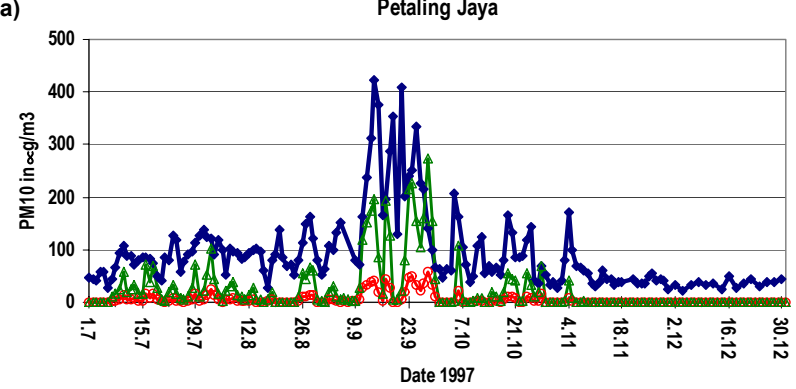

$\rightarrow$ Observation

$\rightarrow$ REMO standard emission

$\triangle$ REMO high emission

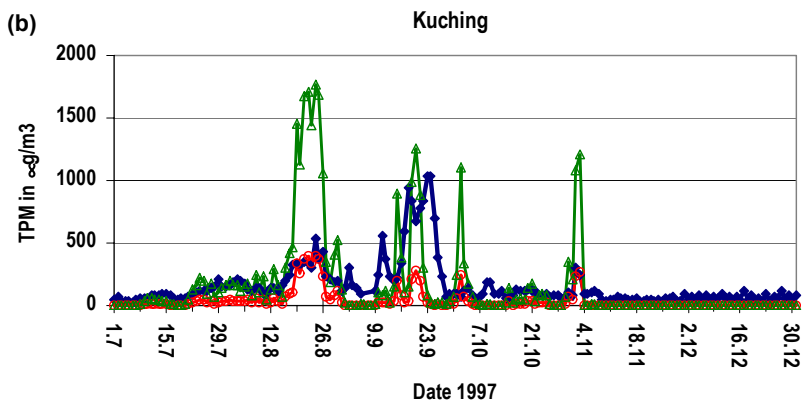

Fig. 9. Daily mean ambient particle concentrations in $\mu \mathrm{g} / \mathrm{m}^{3}$ at (a) Petaling Jaya on Peninsula Malaysia as PM10 and at (b) Kuching on Borneo-Malaysia as TPM. REMO model results derived with the standard and high emission estimate are compared with measurements.

South China Sea, including large areas of western Borneo. In the standard emission case, monthly mean TPM concentration in September are 300 to $1000 \mu \mathrm{g} / \mathrm{m}^{3}$ in the western parts of Borneo. For comparison, sparse measurements in Indonesia show ambient particle concentrations above $2000 \mu \mathrm{g} / \mathrm{m}^{3}$ TPM at several locations in Kalimantan and Sumatra during this time. Concentrations of up to around $4000 \mu \mathrm{g} / \mathrm{m}^{3}$ TPM are recorded in the vicinity to the main fire activity (Palangkaraya on Kalimantan and Jambi on Sumatra) (Heil and Goldammer, 2001). This comparison indicates that the high emission case overestimates observed TPM concentrations near the fires while the standard emission case approximately meets the range of observed concentrations in the vicinity of the fires.

\subsubsection{Smoke-haze at Malaysian locations}

To evaluate the modelled atmospheric TPM distribution downwind of the main fires in more detail, we quantitatively compare REMO simulation results with ambient particle measurements obtained from the Malaysian Meteorological Services for seven Malaysian sites for July to December 1997. Dependent on the station, particle measurements represent daily average concentrations of PM10 (Particulate Matter smaller than $10 \mu \mathrm{m}$ in diameter) or TPM based on continuous (daily) or discontinuous (every second day) measurements. If we compare model results with PM10 measurements, we convert TPM concentrations derived from the model simulations into PM10 assuming a PM10/TPM ratio of $80 \%$. This ratio is based on emission factors given by Peterson and Ward (1993) for fuel combustion (large woody, litter and duff) in the smouldering stage.

Figure 9 illustrates PM10 and TPM observations at Petaling Jaya on Peninsular Malaysia about $800 \mathrm{~km}$ downwind of the main fire regions and Kuching on Borneo-Malaysia, $400 \mathrm{~km}$ downwind of the fires, from July to December 1997 together with the corresponding REMO model results for the first model layer derived with the standard and high emission estimate. In early July 1997 and after mid-November, i.e. before and after the smoke-haze episode, background particle concentrations between 40 and $60 \mu \mathrm{g} / \mathrm{m}^{3}$ are measured at both locations. This approximate particle background is missing in the REMO model results because we included solely primary particles released by vegetation and peat fires in our simulations, no other anthropogenic or natural particle sources and no secondary aerosol formation. PM10 measurements at Petaling Jaya show a gradual, but highly fluctuating increase during July and August, followed by a distinct rise in September with peak values around $400 \mu \mathrm{g} / \mathrm{m}^{3}$ PM10. Particle concentrations return to background levels in mid-November. The REMO model reproduces the temporal development of ambient particle concentration at Petaling Jaya with a linear correlation coefficient between observation and model output of $\mathrm{R}=0.66$. When taking into account a constant background value of $50 \mu \mathrm{g} / \mathrm{m}^{3}$, the peak values of particle concentrations in the high emission case are very similar to the measured concentrations, they exceed the measurements only during a few days. With the standard emission estimate peak concentration plus background concentrations reach $100 \mu \mathrm{g} / \mathrm{m}^{3}$ in maximum at Petaling Jaya and thus clearly underestimate observed concentrations. Measured particle concentration at Kuching also peaked in September with maximum values around $1000 \mu \mathrm{g} / \mathrm{m}^{3}$ TPM. The REMO model reproduces the temporal variability of TPM concentrations observed at Kuching only moderately $(\mathrm{R}=0.44)$. At this location the high emission estimate overpredicts observed concentrations whereas the standard emission estimates shows better agreement with observations, although it underestimates the September peak values.

Figure 10 illustrates the differences between observed TPM and PM10 concentrations and REMO model results for the standard emission estimate (Fig. 10a) and the high emission estimate (Fig. 10b) at the seven Malaysian locations from July to December 1997. Negative values represent model overprediction, positive values model underprediction. A bias of about $30-100 \mu \mathrm{g} / \mathrm{m}^{3}$ is visible outside the smoke-haze period due to the neglected particle background concentrations in the REMO model simulations. The 
highest deviations from observations occur at Kuching. High correlation $(\mathrm{R}>0.73)$ is found for particulate matter concentrations measured on Peninsular Malaysia at Ipoh, Petaling Jaya, Kuantan and Melaka throughout the fire episode (1 July to 15 November 1997), but no correlation is found for the post-haze period (16 November to 31 December 1997). This indicates that during the smoke-haze episode these locations are to a large degree influenced by the same air masses loaded with fire aerosols. REMO model results determined with the standard emission estimate differ from the observations on Peninsula Malaysia in maximum by $+400 \mu \mathrm{g} / \mathrm{m}^{3}$ and $-100 \mu \mathrm{g} / \mathrm{m}^{3}$. Model results calculated with the high emission estimate show an underprediction of $400 \mu \mathrm{g} / \mathrm{m}^{3}$ of the measurements on Peninsula Malaysia and a significant higher overprediction up to $600 \mu \mathrm{g} / \mathrm{m}^{3}$. The underpredicted values at the Malaysian stations show to a large degree a comparable pattern with both emission estimates, pointing to processes that affected atmospheric particle concentrations during long range transport in a similar way. Here uncertainties in the modelled precipitation especially over the South China Sea due to the forecast mode application, the convective cloud module or the prescribed sea surface temperature (SST) are revealed.

In summary, with the standard emission estimate particle concentrations in the vicinity of the fires can be reproduced well, but they are generally underestimated on Peninsula Malaysia. Using the high emission estimate, REMO model results clearly exceed observed particle concentrations close to the fires but at locations in Malaysia affected by long-range transport of fire emissions only a relatively small overestimation remains. It should be emphasised again, that principally a model underpredication of atmospheric particle concentrations is expected, because only primary emissions of particles released from the fires are considered, no secondary aerosol formation and no other anthropogenic or natural particle sources are included. Additionally, the overestimation of precipitation and related wet deposition tends to remove too much particles from the atmosphere in our model calculation. For these reasons, the model simulation using the high emission estimate is pointing to an overestimation of the vegetation and peat fire emissions and the assumed peat area burned in Indonesia in 1997/1998.

\section{Conclusions and outlook}

Numerical model simulations of the severe smoke-haze periods in Indonesia during 1997/1998 have been carried out with the regional atmosphere-chemistry model REMO (Langmann, 2000). The model experiments focussed on the dispersion of vegetation and peat fire emissions in the atmosphere using two emission inventories, which have been set up by modifying the size of the fire affected peat areas only. Although the model simulations are carried out with a number of simplifications and assumptions, conclusions (a)

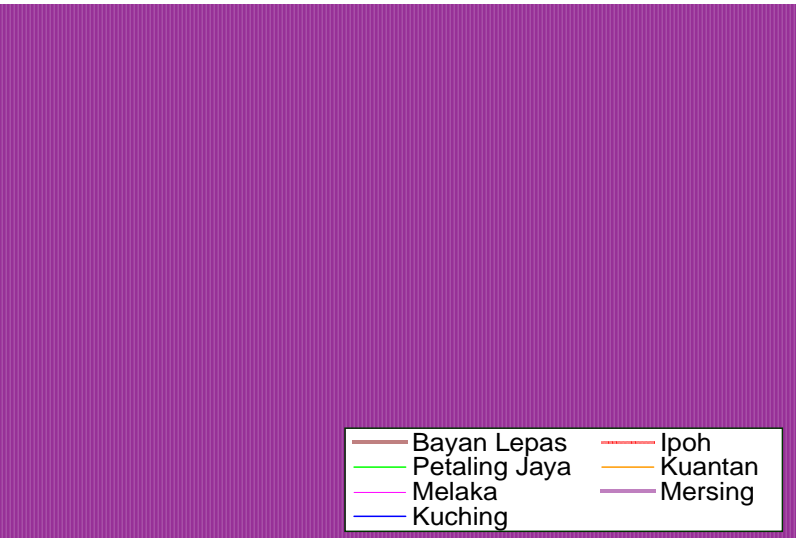

(b)

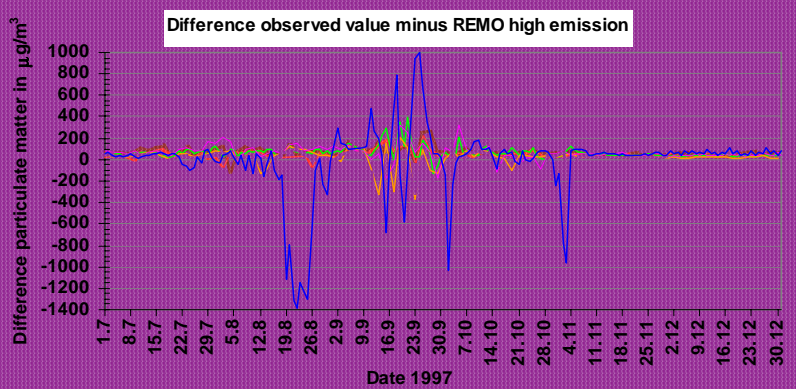

Fig. 10. Difference between observed ambient particle concentrations (TPM Lepas, Ipoh, Melaka and Kuching and PM10 for Petaling Jaya, Kuantan and Mersing) and corresponding REMO model results for (a) the standard emission estimate and (b) the high emission estimate.

on the total particulate and gaseous emissions released from the Indonesian fires in 1997/1998 can be drawn from comparison of modelled particle concentrations with available measurements. The high emission estimate with the total of $1600 \mathrm{MtC}\left(83 \% \mathrm{CO}_{2}, 14 \% \mathrm{CO}, 2 \%\right.$ TPM-carbon and $1 \%$ $\mathrm{CH}_{4}$ ) overestimates observed particle concentrations close to the fires. Downwind of the fires on Peninsula Malaysia the particle load is overestimated by the high emission estimate up to $600 \mu \mathrm{g} / \mathrm{m}^{3}$ at several locations, a value that significantly exceeds ambient air quality standards. With the standard emission estimate ( $380 \mathrm{MtC}$ total emissions) observed particle concentrations in the vicinity of the main fires are much better reproduced, but downwind of the fires observed particle concentrations tend to be underpredicted. Here it has to be noted that a principal underprediction of modelled atmospheric particle concentrations is expected as outlined in the discussion in Sect. 4. Therefore, we conclude that a release of $1600 \mathrm{MtC}$ overestimates the vegetation and peat fire emissions in Indonesia in 1997/1998. We also conclude that the area of the fire affected peatlands which is based on Page et al. (2002) in the high emission case, is too large. 
Burning peat areas in Indonesia have been a major source of gases and particles in recent smoke-haze events (Nichol, 1997; Levine, 1999; Page et al., 2002). Therefore, continuous monitoring of peat areas in Indonesia is necessary, particularly of the spatial distribution, depth and modification by fire. Such information helps to reduce the huge uncertainties in emission estimates of smoke haze particles, $\mathrm{CO}_{2}, \mathrm{CO}$, $\mathrm{CH} 4$ and other trace gases for impact assessments of human health and climate change. Estimates of $\mathrm{CO}_{2}$ emissions from burning peatlands in Indonesia in 1997 range from 13\% to $40 \%$ (Page et al., 2002) of the mean global carbon emissions from fossil fuels. The reason for the measured large atmospheric $\mathrm{CO}_{2}$ increase in 1997/1998 (IPCC, 2001), however, is still in discussion in the carbon cycle community. One possibility is also decreased photosynthesis of vegetation in the Amazon region due to decreased rainfall during the El Niño period (Scholze, 2003). Rödenbeck et al. (2003) and van der Werf et al. (2004) emphasised recently such anomalies in CO and $\mathrm{CO}_{2}$ emissions from tropical South America during the El Niño event 1997/1998.

Repeated smoke-haze periods in Indonesia in recent years caused mainly by peat fires are a major threat to human health. Due to the lack of continuous countrywide measurements of air quality in Indonesia, numerical model simulations as presented here with the REMO model are an important tool to assess the sources, the amount and distribution of smoke-haze particles in the atmosphere over Indonesia and the possible impact on human health. Further developments are necessary to improve the quality of the simulation results. These include particularly the formation of secondary organic aerosols from low volatile organic compounds and the prediction of the chemical composition and size distribution of the smoke-haze particles.

Another key factor when modelling smoke-haze is the prediction of rainfall because wet deposition is the major removal process of smoke-haze particles from the atmosphere. As outlined by Aldrian (2003) and also in this paper, the REMO model tends to overestimate rainfall in Indonesia, especially over the ocean. During the winter monsoon season when the air masses approach from the Asian continent the model might overpredict precipitation because aerosol-cloud interactions in these polluted air masses are not taken into account. Locally, the influence of smoke-haze aerosols on clouds and precipitation could be important for a suppression of rainfall (Rosenfeld, 1999) and therefore a prolongation of the fires. Aldrian (2003) pointed to the importance of the local SST. With a coupled ocean-atmosphere model approach with variable SST, he was able to improve the determination of rainfall significantly. Another possibility to improve rainfall prediction is to take into account a fractional land-sea coverage in each grid cell according to Semmler et al. (2004) to represent the numerous small islands of Indonesia more realistically. As these islands act as heat engines for local convection in this most active convective region of the world, the effect is assumed be important. Neale and Slingo (2003) analysed the performance of a global circulation model over Indonesia and showed that the non-representation of islands lead to an overall increase in precipitation. Moreover, the approach how to describe convective processes in the model has to be examined carefully.

Acknowledgements. The authors would like to thank E. Aldrian, S. Hagemann, J. Hölzemann, A. Hoffmann, L. Kornblueh, M. Pfeffer and R. Podzun for support and valuable comments. The availability of data from ATRS, TOMS AI, GPCC and the Malaysian Meteorological Service is gratefully acknowledged. This work has been funded by the German Ministry for Education, Science, Research and Technology (BMBF) within the Focus Program AFO2000.

Edited by: M. Heimann

\section{References}

ADB (Asian Development Bank)/BAPPENAS (National Development Planning Agency): Causes, Extent, Impact and Costs of 1997/98 Fires and Drought Final Report, Annex 1 and 2, Planning for Fire Prevention and Drought Management Project , Asian Development Bank TA 2999INO Fortech, Pusat Pengembangan Agribisnis, Margueles Pöyry, Jakarta, Indonesia, http://www.adb.org/Documents/ Reports/Fire_Prevention_Drought_Mgt/default.asp, 1999.

Ahmad-Zainal, M. I.: Forest Fire in Malaysia: Its Management and Impact on Biodiversity, Asean. Biodiv., 1(3), 31-35, 2001.

Aldrian, E.: Simulations of Indonesian rainfall with a hierarchy of climate models, PhD thesis, Examination Report No. 92, Max-Planck-Institute for Meteorology, Hamburg, Germany, http: //www.sub.uni-hamburg.de/disse/1090/dissertation.pdf, 2003.

Anderson, I. P.: NOAA/GIS Training Expert, http: //mofrinet.cbn.net.id/informasi/PHPA/FFPCP/PDF/

NOAA_GIS_Training_Expert_final_report.PDF, 2001.

Arino, O. and Rosaz, J.-M.: 1995 to 1999 ATSR World Fire Atlas, Proceeding of the Joint Fire Science Conference, Boise, 15-17 June, 1999.

Balasubramania, R., Quian, W.-B., Decessi, S., Facchini, M. C., and Fuzzi, S.: Comprehensive characterisation of PM2.5 aerosols in Singapore, J. Geophys. Res., 108 (D16), 4523, doi:10.1029/2002JD002517, 2003.

Chevillard, A., Ciais, P., Karstens, U., Heimann, M., Schmidt, M., Levin, I., Jacob, D., Podzun, R., Kazan, V., Sartorius, H., and Weingartner, E.: Transport of Rn-222 using the regional model REMO: a detailed comparison with measurements over Europe, Tellus B, 54, 850-871, 2002a.

Chevillard, A., Karstens, U., Ciais, P., Lafon, S., and Heimann, M.: Simulation of atmospheric $\mathrm{CO}_{2}$ over Europe and western Siberia using the regional scale model REMO, Tellus B, 54, 872-894, 2002 b.

Dierke Weltatlas: Georg Westermann Verlag, Braunschweig, Germany, 140-141, 1980.

Duncan, B. N., Bey, I., Chin, M., Mickley, L. J., Fairlie, T. D., Martin, R. V., and Matsueda, H.: Indonesian Wildfires of 1997: Impact on Tropospheric Chemistry, J. Geophys. Res., 108 (D15), 4458, doi:10.1029/2002JD003195, 2003.

FAO (Food and agriculture organisation of the United Nations): FAO/WFP Crop and food supply assessment mission to Indone- 
sia, Special report, 17th April 1998, FAO Rome, http://www.fao. org/DOCREP/004/W8458E/W8458E00.HTM, 1998.

Heil, A. and Goldammer, J. G.: Smoke-haze pollution: A review of the 1997 episode in South-east Asia, Regional Env. Change, 2 (1), 24-37, 2001.

Herman, J. R., Krotkov, N., Celarier, E., Larko, D., and Labow, G.: Distribution of UV radiation at the Earth's surface from TOMS-measured UV-backscattered radiances, J. Geophys. Res., 104 (D10), 16911-16 922, 1999.

Huffman, G. J., Adler, R. F., Arkin, P., Chang, A., Ferraro, R., Gruber, A., Janowiak, J., McNab, A., Rudolf, B., and Schneider, U.: The Global Precipitation Climatology Project (GPCP) combined precipitation data set, Bull. Am. Meteor. Soc., 78, 5-20, 1997.

IPCC, Climate Change 2001: The scientific basis, edited by: Houghton, J. T., Ding, Y., Griggs, D. J., et al., Cambridge University Press, Cambridge, UK, 2001.

Jacob, D.: Investigation of the Annual and Interannual Variability of the Water Budget over the Baltic Sea Drainage Basin Using the Regional Climate Model REMO, Meteorol. Atmos. Phys., 77 (1-4), 61-73, 2001.

Kirono, D. C. G, Tapper, N. J., and McBride, J.: Documenting Indonesian rainfall in the 1997-1998 El Niño event, Phys. Geogr., 20 (5), 422-435, 1999.

Langmann, B., Herzog, M., and Graf, H.-F.: Radiative forcing of climate by sulfate aerosols as determined by a regional circulation chemistry transport model, Atmos. Environ., 32, $2757-$ 2768,1998

Langmann, B.: Numerical modelling of regional scale transport and photochemistry directly together with meteorological processes, Atmos. Environ., 34, 3585-3598, 2000.

Langmann, B. and Graf, H.-F.: Indonesian smoke aerosols from peat fires and the contribution from volcanic sulfur emissions, Geophys. Res. Lett., 30 (11), 1547, doi:10.1029/2002GL016646, 2003.

Langmann, B., Bauer, S. E., and Bey I.: The influence of the global photochemical composition of the troposphere on European summer smog, Part I: Application of a global to mesoscale model chain, J. Geophys. Res., 108 (D4), 4146, doi:10.1029/2002JD002072, 2003.

Levine, J. S.: The 1997 fires in Kalimantan and Sumatra, Indonesia: Gaseous and particulate emissions, Geophys. Res. Lett., 26 (7), 815-818, 1999.

Loveland, T. R., Reed, B. C., Brown, J. F., Ohlen, D. O., Zhu, J., Yang, L., and Merchant, J. W.: Development of a Global Land Cover Characteristics Database and IGBP DISCover from 1-km AVHRR Data, Int. J. Remote Sens., 21 (6/7), 1303-1330, 2000.

Majewski, D.: The Europa Modell of the Deutscher Wetterdienst, Seminar proceedings ECMWF, 2, 147-191, 1991.

Malingreau, J. P.: The contribution of remote sensing to the global monitoring of fires in tropical and subtropical ecosystems, in: Fires in the tropical biota, Ecosystems process and global change, edited by: Goldammer, J. G., Ecological studies 84, Springer-Verlag, Berlin, Heidelberg, New York, 337-370, 1990.

McPhaden, M. J.: Genesis and Evolution of the 1997-98 El Niño, Science, 950-954, 1999.

Mellor, B. and Yamada, T.: A hierachy of turbulence closure models for planetary boundary layers, J. Atmos. Sci., 31, 1791-1806, 1974.
Mesinger, F. and Arakawa, A.: Numerical methods used in atmospheric models, GARP Public. Ser., 17, 1-64, 1976.

Mestayer, P., Almbauer, R., and Tchepel, O.: Urban Field Campaigns, edited by Moussiopoulos, N., Air Quality in Cities, Springer, Berlin, 51-87, 2003.

Narukawa, M., Kawamura, K., Takeuchi, N., and Nakajima, T.: Distribution of dicarboxylic acids and carbon isotopic composition in aerosols from 1997 Indonesian forest fires, Geophys. Res. Lett., 26, 3101-3104, 1999.

Neale, R. B. and Slingo, J. M.: The Maritime Continent and its role in the global circulation: A GCM study, J. Clim., 16 (5), 834848,2003

Nichol, J.: Bioclimatic impacts of the 1994 smoke haze event in Southeast Asia, Atmos. Environ., 31 (8), 1209-1219, 1997.

Okada, K., Ikegami, M., Zaizen, Y., Makino, Y., Jensen, J. J., and Gras, J. L.: The mixture of individual aerosol particles in the 1997 Indonesian haze episode, J. Aerosol Sci., 32, 1269-1729, 2001.

Page, S. E, Siegert, F., Rieley, J. O., Böhm, H.-D. V., Jaya, A., and Limin, S.: The amount of carbon released from peat and forest fires in Indonesia during 1997, Nature, 420, 61-65, 2002.

Peterson, J. and Ward, D.: An inventory of particulate matter and air toxic emissions from prescribed fires in the United States for 1989, IAG \# DW12934736-01-0-1989, 1993.

Ramage, C. S.: Monsoon meteorology, Academic Press, New York, 1971.

Rieley, J. O., Page, S., and Sieffermann, G.: Tropical peat swamp forests of Southeast Asia: Ecology and environmental Importance, Malaysian J. Trop. Geogr., 26 (2), 131-141, 1995.

Rieley, J. O., Page, S. E., and Shepherd, P. A.: Tropical Bog Forests of South East Asia, in: Conserving Peatlands, edited by: Parkyn, L., Stoneman, R. E. and Ingram, H. A. P., Wallingford, CAB International, 35-41, 1997.

Roeckner, E., Arpe, K., Bengtsson, L., Christoph, M., Claussen, M., Dümenil, L., Esch, M., Giorgetta, M., Schlese, U., and Schulzweida, U.: The atmospheric general circulation model ECHAM-4: Model description and simulation of present-day climate, Report No. 218, Max Planck Institute for Meteorology, Hamburg, Germany, 1996.

Rödenbeck, C., Houweling, S., Gloor, M., and Heimann, M.: $\mathrm{CO}_{2}$ flux history 1982-2001 inferred from atmospheric data using a global inversion of atmospheric transport, Atmos. Chem. Phys., 3, 1919-1964, 2003,

SRef-ID: 1680-7324/acp/2003-3-1919.

Rosenfeld, D.: TRMM Observed First Direct Evidence of Smoke from Forest Fires Inhibiting Rainfall, Geophys. Res. Lett., 26 (20), 3105-3108, 1999

Scholze, M.: Model studies on the response of the terrestrial carbon cycle to climate change and variability, Ph.D. thesis, Examination Report No.90, Max-Planck-Institute for Meteorology, Hamburg, Germany, http://www.sub.uni-hamburg.de/disse/ 1007/dissertation.pdf, 2003.

Semmler, T., Jacob, D., Schlünzen, K. H., and Podzun, R.: Influence of sea ice treatment in a regional climate model on boundary layer values in the Fram Strait region, Month. Weath. Rev., 132, 985-999, 2004.

Shimada, S., Takahashi, H., Haraguchi, A., and Kaneko, M.: Carbon content characteristics of tropical peats in Central Kalimantan, Indonesia: Estimating their spatial variability in density, 
Biogeochem., 53, 249-267, 2001.

Siegert, F. and Hoffmann, A. A.: The 1998 forest fires in East Kalimantan (Indonesia): A quantitative evaluation using high resolution, multitemporal ERS-2 SAR images and NOAA-AVHRR hotspot data, Remote Sens. Environ., 72, 64-77, 2000.

Smolarkiewitz, P. K.: A simple positive definite advection scheme with small implicit diffusion, Mon. Wea. Rev., 111, 479-486, 1983.

Supardi, A., Subekty, D., and Neuzil, S. G.: General geology and peat resources of the Siak Kanan and Bengkalis Island peat deposits, Sumatra, Indonesia, in: Modern and Ancient Coal Forming Environments, edited by: Cobb, J. C. and Cecil, C. B., Geological Society of America Special Paper, 86, 45-61, 1993.

Tiedtke, M.: A comprehensive mass flux scheme for cumulus parameterisation in large-scale models, Mon. Wea. Rev., 117, 1778-1800, 1989.
Walcek, C. J. and Taylor, G. R.: A theoretical method for computing vertical distributions of acidity and sulfate production within cumulus clouds, J. Atmos. Sci., 43, 339-355, 1986.

Walcek, C. J., Brost, R. A., Chang, J. S., and Wesley, M. L.: $\mathrm{SO}_{2}$, Sulfate and $\mathrm{HNO}_{3}$ deposition velocities computed using regional landuse and meteorological data, Atmos. Environ., 20, 949-964, 1986.

van der Werf, G. R., Randerson, J. T., Collatz, G. J., Giglio, L., Kasibhatla, P. S., Arellano, A. F., Olsen, S. C., and Kasichke, E. S.: Continental-scale partitioning of fire emissions during the 1997 to $2001 \mathrm{El}$ Niño/La Niña period, Science, 303, 73-76, 2004.

WMO (World Meteorological Organisation): Report of the WMO Workshop on Regional Transboundary Smoke and Haze in Southeast Asia, Singapore, 2-5 June 1998, WMO, Geneva, SG/59, 1998. 